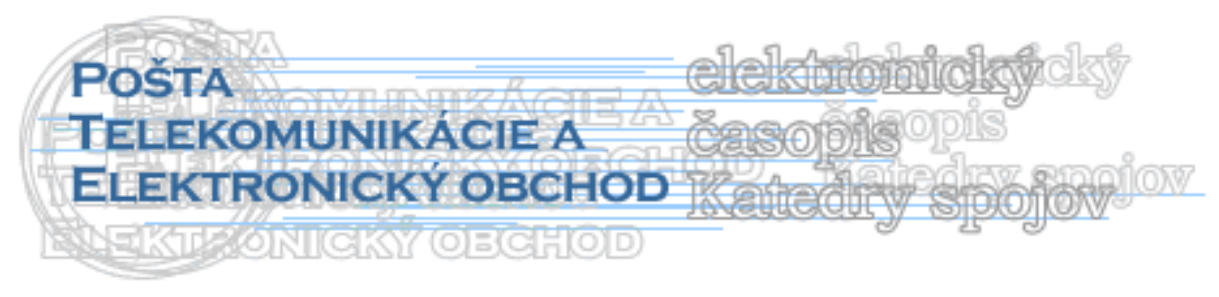

\title{
METÓDY STANOVENIA VNÚTORNEJ HODNOTY AKCIE
}

\section{Lucia Tokarčíková ${ }^{+}$}

Fundamentálna analýza sa považujeme za najdôležitejšiu z metód rozboru cenných papierov. Zaoberá sa stanovením vnútornej hodnoty akcie. V predkladanom článku sú postupne uvedené jednotlivé metódy stanovenia výpočtu vnútornej hodnoty akcie.

\section{Dividendové diskontné modely}

Dividendový diskontný model je v súčasnej dobe najpoužívanejšou metódou stanovenia vnútornej hodnoty akcie. Tento model je založený na princípe súčasnej hodnoty budúcich príjmov plynúcich jej majitel'ovi. Za príjmy sa považujú dividendy a predajná cena. Pokial' by sme držali akciu len jeden rok, potom bude jej vnútorná hodnota rovná súčasnej hodnote dividend získaných na konci prvého roka plus súčasnej hodnote očakávanej predajnej ceny $(\mathrm{P} 1)$. Vnútornú hodnotu je možné tiež vyjadrit' pomocou nasledujúceho vzorca:

$$
V H=\frac{D_{1}+P_{1}}{\left(1+K_{e}\right)}
$$

kde $V H$ je vnútorná hodnota akcie;

$D_{1}$ - očakávaná dividenda na konci prvého roka;

$P_{1} \quad$ - očakávaná predajná cena na konci prvého roka;

$K_{e}$ - požadovaná úroková miera.

Ako určime predajnú cenu na konci prvého roka? Opät' je to hodnota všetkých diskontovaných príjmov pre majitel'a aktíva. Preto platí:

$$
P_{1}=\frac{D_{2}+P_{2}}{\left(1+K_{e}\right)}
$$

kde $P_{1}$ je očakávaná predajná cena na konci prvého roka;

$D_{2}$ - očakávaná dividenda na konci druhého roka;

$P_{2}$ - očakávaná predajná cena na konci druhého roka;

$K_{e}$ - požadovaná úroková miera.

\footnotetext{
${ }^{+}$Ing. Lucia Tokarčíková, externá doktorandka na Katedre spojov, Fakulta prevádzky a ekonomiky dopravy a spojov, Žilinská univerzita v Žiline, Univerzitná 1, 01026 Žilina, Slovenská republika
} 
Rovnicu (1.2) dosadíme do rovnice (1.1) a dostaneme vzt’ah pre výpočet súčasnej hodnoty dividend $\mathrm{v}$ priebehu dvoch rokov plus súčasná hodnota očakávanej predajnej ceny na konci druhého roka. Tento vzt’ah je možné vyjadrit' týmto vzorcom:

$$
V H=\frac{D_{1}}{\left(1+K_{e}\right)}+\frac{D_{2}+P_{2}}{\left(1+K_{e}\right)^{2}}
$$

Pretože na akcie je pozeraná ako nesplatitel'ný cenný papier, je možné tento krok opakovat' po n-rokoch a neustále nahradzovat' jednotlivé hodnoty P. Vnútorná hodnota akcie je potom súčtom súčasnej hodnoty budúcich dividend do n-tého obdobia a súčasnej hodnoty predajnej ceny v n-tom období. N-té obdobie môže byt' nekonečne vzdialené, pretože akcie sú spravidla neumoritel'né. Pokial' sa $n$ blíži k nekonečnu, potom sa súčasná hodnota očakávanej predajnej ceny blíži k nule. Preto je možné predajnú cenu úplne vypustit' a vnútornú hodnotu akcie zapísat' len ako súčasnú hodnotu budúcich dividend:

$$
V H=\frac{D_{1}}{\left(1+K_{e}\right)}+\frac{D_{2}+P_{2}}{\left(1+K_{e}\right)^{2}}+\ldots . .+\frac{D_{n}}{\left(1+K_{e}\right)^{n}}
$$

Tento vzorec je vo finančnej ekonómii nazývaný ako dividendový diskontný model (dividend discount model).

Dividendový diskontný model je najlepšie použitel'ný pre firmy vo fáze expanzie alebo zrelosti, pretože dividendy týchto spoločností sú prognózovatel'né s väčšou presnost'ou a obvykle vytvárajú väčší percentuálny podiel ako kapitálové zisky z celkového výnosu. Profesionálni analytici často ignorujú dividendový diskontný model a kritizujú jeho obmedzenú využitel'nost'. Ich kritika sa opiera o tieto argumenty:

1. dividendový diskontný model nemôže byt používaný pre stanovenie vnútornej hodnoty akcie, ak spoločnost' vypláca vel'mi malé, alebo žiadne dividendy. Rovnako je vel'mi zložité prognózovanie budúcej výšky dividend pri nestabilnej dividendovej politike;

2. dividendový diskontný model predpokladá presnú prognózu dlhodobej rastovej miery dividend. Tieto prognózy sú však po uplynutí $1-2$ rokov vel'mi nepresné;

3. je vel'mi zložité stanovit' vhodnú požadovanú výnosovú mieru, pretože jednotlivé spoločnosti sú ovplyvňované vel'kým množstvom faktorov, ktoré je obtiažne predpovedat' ( napr. inflácia, bezriziková výnosová miera, riziková prémia);

4. dividendový rastový model nie je použitel'ný pre mimoriadne rastové spoločnosti, kde je rastová miera väčšia alebo rovná požadovanej výnosovej miere.

\section{Ziskové modely}

V praktickej činnosti analytikov bývajú ziskové modely používanejšie ako „teoretický“ dividendový diskontný model. Ziskové modely vychádzajú z ukazovatel’a P/E (price-earnings ratio - kurz/zisk). Bežne zverejňovaný ukazovatel’ P/E má tento tvar:

$$
P_{0} / E_{0}=\frac{P_{0}}{E_{0}}
$$

kde $P_{0} / E_{0}$ je hodnota ukazovatel'a; 
$P_{0} \quad$ - aktuálna trhová cena;

$E_{0} \quad$ - posledný zverejnený zisk spoločnosti, ktorý pripadá na jednu akciu.

Ziskové modely sa zaoberajú problémom, prečo majú niektoré spoločnosti vysoké $\mathrm{P} / \mathrm{E}$ a iné zase nízke. Analýzu faktorov tohto ukazovatel'a je možné realizovat' z dvoch pohl'adov. Prvý pohl'ad hl'adá faktory ovplyvňujúce trhovú úroveň ukazovatel'a, ktorý je označovaný PM0/EM0 (price-earnings ratio celého trhu). Druhý prístup analyzuje faktory, ktoré ovplyvňujú $\mathrm{P} 0 / \mathrm{E} 0$ jednotlivých spoločností.

Za najdôležitejší faktor je považovaná inflácia, ktorej vplyv je možné zahrnút’ nasledovne:

- rast inflácie vedie k rastu požadovanej výnosovej miery, čo potom spôsobuje pokles trhovej ceny akcie a PM0/EM0. Medzi faktory, ktoré ovplyvňujú úroveň tohto ukazovatel'a, patria;

- rastové perspektívy a riziká - vysoký očakávaný rast spoločnosti sa odráža vo vysokom P0/E0;

- dividendová politika - jej vplyvy je rôzny pre spoločnosti nachádzajúce sa v odlišných fázach životného cyklu spoločnosti. Pri firmách, ktoré majú vysoké investičné príležitosti, sú nízke dividendy prijatel'né. Zníženie dividend pri firmách vo fáze zrelosti však môže vyvolat' pokles $\mathrm{P} 0 / \mathrm{E} 0$;

- typ odvetvia a jeho popularita medzi investormi - investori často preferujú tie odvetvia, ktoré sa vyznačujú vysokým stupňom využívania technológií a výskumu. V súčasnej dobe sú tieto odvetia populárne;

- kvalita managementu spoločností - akcie spoločnosti s kvalifikovaným, pružným i inovatívnym managementom majú vyšší P0/E0.

Pri hodnotení P0/E0 je nutná opatrnost', pretože tento ukazovat' je vo vel'kej miere ovplyvňovaný použitými účtovnými metódami, ktoré sa v jednotlivých krajinách líšia. Zisk môže byt' tiež podstatne skreslený jednorázovými finančnými a obchodnými operáciami, ktoré nie sú trvalého charakteru. Analytik by sa mal pokúsit' očistit' vykázaný zisk od týchto skutočností.

Ukazovatel' P0/E0 slúži pre ohodnotenie relatívnej úrovne jednotlivých akcií, ale nemôže nám pomôct' pri stanovení vnútornej hodnoty akcie, pretože bežné P0/E0 vynásobené bežným ziskom (E0) sa rovná aktuálnej trhovej cene. Pre stanovenie vnútornej hodnoty akcie je nutné stanovit' ukazovatel' normálne $\mathrm{P} / \mathrm{E}$, ktoré budem d'alej označovat' ako $\mathrm{P} / \mathrm{EN}$ pomocou ktorého je možné vnútornú hodnotu akcie vyjadrit' v nasledujúcej podobe:

$$
V H=E_{1} * P / E_{N},
$$

kde $V H$ je vnútorná hodnota akcie;

$E_{1}$ - očakávaný zisk na jednu akciu v budúcom roku;

$P / E_{N}$ - normálna úroveň $\mathrm{P} / \mathrm{E}$.

Investori a analytici často ignorujú dividendový diskontný model, skôr sledujú akcie v krátkom období, a preto preferujú vyšší spôsob podl'a výrazu (2.2).

Hodnotu normálneho P/EN možno stanovit’ rôznymi metódami, pričom najpoužívanejšími sú:

a/ základná metóda;

b/ regresná metóda. 
a/ Základná metóda vychádza z dividendového diskontného modelu s konštantným rastom, ktorý má tvar:

$$
P=\frac{D_{1}}{K_{e}-g}
$$

kde $P$ je cena, ktorá sa rovná vnútornej hodnote;

$D_{1}$ - očakávaná dividenda na konci prvého roka;

$g$ - konštantná rastová miera dividend;

$K e$ - požadovaná úroková miera.

b/ Regresná metóda patrí medzi štatistické metódy určovania vnútornej hodnoty akcie. Pri tejto metóde je najdôležitejšie identifikovat' a kvantifikovat' faktory, ktoré ovplyvňujú vnútornú hodnotu. Medzi tieto faktory patria:

- očakávaná miera rastu zisku;

- očakávaná výška výplatného pomeru;

- riziková zložka - volatilita zisku.

Výber faktorov závisí na každom analytikovi. Čím viac faktorov, tým je regresný model presnejší, ale tiež zložitejší. Regresná metóda sa pre svoje značné nedostatky pri určovaní P/E nestala v praktickej analýze akciových trhov príliš využívanou. Regresná metóda je využívaná najmä pretože:

- hodnota regresných koeficientov je podstatne ovplyvnená;

- vysvetl'ujúce premenné sú obyčajne navzájom korelované, čo znamená, že regresné koeficienty sú dost' nespol'ahlivé v dôsledku multikolinearity.

\section{Kombinácia dividendového a ziskového modelu}

Ide o kombinovanú metódu, ktorá je založená na $\mathrm{P} / \mathrm{E}$ i na obmedzení dividendovom diskontnom modeli. Model stanoví vnútornú hodnotu akcie ako súčet súčasnej hodnoty budúcich dividend $\mathrm{v}$ časovo obmedzenom období a trhovej ceny akcie k termínu ukončeniu toku dividend. Vnútorná hodnota akcie sa vyjadrí nasledujúcim vzorcom:

$$
V H=P V D_{T}+P V P_{N},
$$

kde $\quad V H$ je vnútorná hodnota akcie;

$P V D_{T}$ - súčasná hodnota všetkých dividend za časovo obmedzené obdobie;

$P V P_{N}$ - súčasná hodnota trhovej ceny, ktorá je stanovená na základe modelu $\mathrm{P} / \mathrm{E}$.

\section{Model vol'ného cash flow}

Pri stanovení vnútornej hodnoty akcie touto metódou, sa najprv musí stanovit' celková hodnota firmy. Vnútorná hodnota akcií sa potom získa tým, že sa od celkovej hodnoty firmy sa odčíta hodnota cudzieho kapitálu. Platí, že: 


$$
C V H=V_{T}-L,
$$

kde $C V H$ je celková vnútorná hodnota akcií;

$V_{T} \quad$ - celková hodnota firmy;

L - celková hodnota záväzkov.

Vnútornú hodnotu akcie získame tak, že celková vnútorná hodnota akcií vydelím počtom vydaných akcií. Vypočítanú hodnotu porovnáme s aktuálnym kurzom na akciovom trhu a zistíme, či je akcia na trhu podhodnotená, či nadhodnotená.

Táto metóda stanovenia vnútornej hodnoty akcie je pomerné náročná. Je spravidla využívaná pri akvizičnej politike firiem a pri priamych investíciách inštitucionálnych investorov.

\section{Historické modely}

Historické modely sú založené na porovnaní priemernej historickej trhovej ceny akcie s d'alšou priemernou historickou veličinou. Analytici sa predovšetkým zameriavajú na priemerné tržby, priemernú výšku dividend, priemernú účtovnú hodnotu a priemerné cash flow. Skupinu tvoria:

a/ Model P/S dáva do pomeru historickú trhovú cenu akcie s priemernou historickou výškou tržieb na jednu akciu. Model môžeme zapísat' v nasledujúcej podobe:

$$
P / S=P_{A} / S_{A}
$$

kde $P_{A}$ je priemerná historická trhová cena akcie;

$S_{A}$ - priemerná historická výška tržieb na jednu akciu.

Vnútornú hodnotu akcie získame vynásobením ukazovatel'a $\mathrm{P} / \mathrm{S}$ očakávanou výškou tržieb pre budúci rok $\left(S_{1}\right)$

$$
V H=P / S * S_{1}
$$

b/ Model P/D dáva do pomeru priemernú historickú trhovú cenu akcie s priemernou historickou výškou dividend na jednu akciu. Model môžeme zapísat' v nasledujúcej podobe:

$$
P / D=P_{A} / D_{A}
$$

kde $P_{A}$ je priemerná historická trhová cena akcie;

$D_{A}$ - priemerná historická výška dividend na jednu akciu.

Vnútornú hodnotu akcie získame vynásobením ukazovatel’a P/D očakávanou výškou dividend na jednu akciu pre budúci rok (D1):

$$
V H=P / D^{*} D_{1},
$$

c/ Model P/BV porovnáva priemernú historickú trhovú cenu akcie s priemernou historickou výškou účtovnej hodnoty na jednu akciu. Model môžeme zapísat' v nasledujúcej podobe:

$$
P / B V=P_{A} / B V_{A},
$$


kde $P_{A}$ je priemerná historická trhová cena akcie;

$B V_{A}$ - priemerná historická výška účtovnej hodnoty na jednu akciu.

Vnútornú hodnotu akcie získame vynásobením ukazovatel’a P/BV očakávanou výškou účtovnej hodnoty na jednu akciu pre budúci rok (BV1):

$$
V H=P / B V * B V_{1},
$$

d/ Model P/CF dáva do pomeru historickú trhovú cenu akcie s priemernou historickou výškou cash flow na jednu akciu. Model môžeme zapísat' v nasledujúcej podobe:

$$
P / C F=P_{A} / C F_{A},
$$

kde $P_{A}$ je priemerná historická trhová cena akcie;

$C F_{A}$ - priemerná historická výška účtovnej hodnoty na jednu akciu.

Vnútornú hodnotu akcie získame vynásobením ukazovatel’a P/CF očakávanou výškou cash flow na akciu pre budúci rok (CF1):

$$
V H=P / S * C F_{1},
$$

Historické modely sa používajú najmä na zistenie, či je aktuálna trhová cena vyššia ako priemerná historická úroveň, alebo či je naopak na nižšej úrovni. Historické modely pracujú s veličinami (tržby, dividendy, účtovná hodnota, cash flow), ktoré vykazujú nižšiu volatilitu ako samotný zisk spoločnosti. Historické modely sú preto viac stabilné a môžu generovat' „reálnejšie“ hodnoty. Metódy stanovenia vnútornej hodnoty na princípe historických modelov sú používané ako doplnkové k modelom založeným na dividendách, alebo na zisku spoločnosti.

Záver

Najväčšia pozornost' by mala byt' venovaná metódam, ktoré sú založené na princípe samostatne produkujúceho podniku. Na tomto princípe je založený dividendový diskontný model, ziskový model, alebo cash flow.

V súčasnej dobe historický model P/S, ktorý dáva do pomeru cenu akcie s tržbami na akciu. Tento model je vynikajúcou pomocnou informáciou pred model využívajúci ukazovatel' $\mathrm{P} / \mathrm{E}$, pretože tržby sú na rozdiel od zisku menej volatilné a management podniku môže s tržbami manipulovat' ovel'a obtiažnejšie ako so ziskom. Na druhej strane ukazovatel' $\mathrm{P} / \mathrm{S}$ neberie vôbec do úvahy schopnost' podniku kontrolovat' náklady spoločnosti. 


\section{Literatúra}

[1] CHOVANCOVÁ, B. - JANKOVSKÁ, A. - KOTLEBOVÁ, J. - ŠTURC, B.: Finančný trh. Eurounion, Bratislava, 2002, ISBN 80-88984-31-9

[2] HORNIAKOVÁ, L.: Cenné papiere a finančný trh. Vydavatel'ské oddelenie právnickej fakulty UK, 1995

[3] MUSÍLEK, P.: Finanční trhy a investiční bankovnictví. ETC Publishing, Praha, 1999 